\title{
MANAJEMEN KURIKULUM, KOMITMEN DAN KINERJA MENGAJAR GURU SEKOLAH DASAR
}

\author{
Oleh: \\ Tri Chusniyatul Maromy \\ Badan Penelitian Dan Pengembangan Kemendikbud \\ (E-mail: maromy@,kemdikbud.go.id)
}

\begin{abstract}
ABSTRAK
Penelitian ini dilatarbelakangi karena belum kinerja mengajar guru Sekolah Dasar Negeri di Kota Bandung yang diduga disebabkan oleh kurang optimalnya manajemen kurikulum dan komitmen guru. Penelitian ini bertujuan mendeskripsikan dan menganalisa pengaruh dari manajemen kurikulum dan komitmen guru terhadap kinerja mengajar guru Sekolah Dasar Negeri di Kota Bandung. Penelitian ini menggunakan metode deskriptif dengan pendekatan kuantitatif. Alat pengumpulan data yang digunakan adalah kuisioner. Sampel penelitian adalah 30 SD Negeri di kota Bandung dengan responden berjumlah 164 guru dan 30 kepala sekolah. Hasil penelitian ini menunjukkan bahwa kinerja mengajar guru Sekolah Dasar Negeri di Kota Bandung berada pada kategori sangat tinggi. Sementara manajemen kurikulum pada kategori sangat tinggi, dan komitmen guru pada kategori sangat tinggi. Secara parsial, manajemen kurikulum dan komitmen guru memberikan pengaruh yang positif dan signifikan terhadap kinerja mengajar. Begitupun jika dilihat secara bersama-sama, kedua variabel tersebut memberikan pengaruh yang kuat dan signifikan terhadap kinerja mengajar guru. Rekomendasi penelitian ini yaitu kepala sekolah dapat meningkatkan manajemen kurikulum di sekolahnya, khususnya dari sisi pelaksanaan kurikulum serta membantu guru dalam mengembangkan kompetensi dan keterampilan yang dimilikinya dengan mengambil langkah-langkah yang dapat meningkatkan kinerja mengajarnya.
\end{abstract}

Kata kunci: Kinerja Mengajar, Komitmen Guru, Manajemen Kurikulum

\section{ABSTRACT}

This research was carried out by the lack of teaching performance of state elementary school teachers in Bandung, which was allegedly caused by a lack of optimal curriculum management and teacher commitment. This study aims to describe and analyze the influence of curriculum management and teacher commitment to the performance of teaching elementary school teachers in the city of Bandung. This study uses a descriptive method with a quantitative approach. The data collection tool used is a questionnaire. The study sample was 30 Public Elementary Schools in Bandung with respondents totaling 164 teachers and 30 principals. The results of this study indicate that the teaching performance of state elementary school teachers in the city of Bandung is in the very high category. While curriculum management in the category is very high, and teacher commitment in the category is very high. Partially, curriculum management and teacher commitment have a positive and significant influence on teaching performance. Likewise if viewed together, these two variables have a strong and significant influence on teacher teaching performance. The recommendations of this study are that principals can improve curriculum management in their schools, especially in terms of implementing the curriculum and assisting teachers in developing their competencies and skills by taking steps that can improve their teaching performance.

Keywords: Curriculum Management, Teacher's Commitment, Teaching Performance

\section{PENDAHULUAN}

Sistem pendidikan yang berkualitas dan berdaya saing berdampak positif pada pembentukan generasi muda masa depan. Hal ini sejalan dengan tujuan pendidikan yang tertuang dalam Undang-undang Republik Indonesia Nomor 20 Tahun 2003 tentang Sistem Pendidikan Nasional. Oleh karena itu, upaya peningkatan mutu pendidikan harus memperhitungkan mutu guru, yang meliputi kinerja guru, kompetensi guru, pendidikan profesi guru, dan pengembangan professional berkelanjutan (Satori, 2016).

Guru merupakan salah satu komponen penting dalam kegiatan belajar mengajar. Guru adalah pendidik yang bertugas untuk mendidik, melatih, membimbing dan mengembangkan potensi siswa. Selain itu, guru juga memiliki peranan penting untuk membantu siswa mempermudah dalam hal pemahaman dan menjadi orang yang dipercaya dalam membangun 
komunikasi empati dengan siswa sehingga integritas siswa yang terbangun bukan hanya intelektualitasnya saja tetapi juga dimensi sosial dan spiritualnya (Komariah \& Triatna, 2005).

Dalam menjalankan profesionalitas kerjanya, guru berkewajiban untuk merencanakan pembelajaran, melaksanakan proses pembelajaran yang bermutu, serta menilai dan mengevaluasi hasil pembelajaran. Guru berperan penting dalam menentukan keberhasilan proses pembelajaran sesuai dengan kewajibannya tersebut. Pelaksanaan tugas pokok tersebut dapat menceminkan kinerja mengajar guru yang selanjutnya akan berpengaruh terhadap mutu proses pembelajaran dan mutu pendidikan.

Armstrong (2009) mendefinisikan kinerja sebagai catatan atas pencapaian seseorang. Apabila dikaitkan dengan profesi guru, kinerja mengajar guru dapat diartikan sebagai cara untuk menjalankan tugas pokoknya, yaitu dalam hal perencanaan proses pembelajaran, pengajaran, dan penilaian yang dilakukan dalam rangka mencapai tujuan yang telah ditetapkan (Jones, Jenkin, \& Lord, 2006).

Mulyana (2010) kinerja guru dapat dicapai dengan sukses apabila guru mempunyai komitmen pada siswa dan proses belajarnya, guru menguasai secara mendalam bahan atau materi yang diajarkan kepada siswa, guru bertanggung jawab untuk memantau hasil belajar siswa melalui berbagai teknik evaluasi, mulai dari cara pengamatan dalam perilaku siswa sampai tes hasil belajar, guru mampu berpikir sistimatis tentang apa yang dilakukannya, dan belajar dari pengalamannya, dan selanjutnya guru menyadari bahwa dirinya merupakan bagian dari masyarakat belajar dalam lingkungan profesinya.

Berdasarkan hasil observasi awal, kondisi di lapangan terkait kinerja mengajar guru sekolah dasar di Kota Bandung masih belum optimal. Guru masih disibukkan dengan kegiatan administratif di luar tugas mengajarnya. Kemudian, masih banyak guru yang kesulitan dalam hal perencanaan dan penilaian pembelajaran yang mengacu pada kurikulum yang baru.

Selain itu, berdasarkan penelitian yang dilakukan oleh Anggraeni (2016), sebagian guru sekolah dasar di Kota Bandung masih memiliki disiplin mengajar yang rendah, sekitar 30\% guru tidak berasal dari pendidikan keguruan, dan nilai UKG masih berada dibawah standar yaitu berkisar antara $20-30 \%$. Selanjutnya ditinjau dari data Jendela Pendidikan dan Kebudayaan (http://jendela.data.kemdikbud.go.id), sekitar 86\% dari jumlah guru sekolah dasar sudah memenuhi syarat untuk mengajar karena sudah berkualifikasi pendidikan sarjana (S1) dan sekitar 14\% guru masih memiliki kualifikasi di bawah sarjana (S1).

Armstrong (2009) menyatakan bahwa faktor yang memengaruhi kinerja adalah atribut individu, usaha kerja serta dukungan organisasi. Dengan demikian, salah satu faktor yang mempengaruhi kinerja mengajar guru dari faktor organisasi adalah manajemen kurikulum di sekolah.

Kegiatan manajemen kurikulum dititikberatkan pada usaha-usaha pembinaan situasi belajar mengajar di sekolah agar selalu terjamin kelancarannya (Suryosubroto, 2010). Keberadaan kurikulum tidak saja dapat dilihat dari hasil belajar siswa, tetapi proses ke arah itu yang ditandai dengan adanya analisis kurikulum, penyusunan silabus, dan berbagai perangkat program kurikulum yang dimaksudkan sebagai penyediaan layanan pembelajaran terbaik bagi siswa (Komariah \& Triatna, 2005).

Tercatat sejak kemerdekaan Republik Indonesia, sudah terjadi beberapa kali pergantian 
kurikulum. Perubahan dan pergantian kurikulum dilatarbelakangi oleh perkembangan zaman dan adanya tantangan dunia pendidikan baik dari segi internal maupun eksternal.

Pada kurikulum untuk jenjang sekolah dasar, pengembangan yang dilakukan adalah digunakannya pendekatan tematik terpadu dimana mata pelajaran akan lebur dalam tema-tema yang menjadi pokok bahasan yang disebut juga pembelajaran tematik integratif. Pembelajaran tematik integratif merupakan pendekatan pembelajaran yang mengintegrasikan berbagai kompetensi dari berbagai mata pelajaran ke dalam berbagai tema. Dengan adanya perubahan kurikulum ini, kepala sekolah dan guru sekolah dasar dituntut untuk melakukan pengelolaan atau manajemen kurikulum sesuai dengan tujuan kurikulum.

Manajemen Kurikulum pada hakikatnya membahas tentang pengorganisasian sumbersumber yang ada di sekolah sehingga kegiatan manajemen kurikulum ini dapat dilakukan dengan efektif dan efisien. Kegiatan-kegiatan yang termasuk dalam manajemen kurikulum meliputi pembagian tugas guru, penyusunan jadwal pelajaran, pembagian rombongan belajar, membuat absensi guru dan siswa, menetapkan kegiatan ekstra kurikuler, membuat daftar nilai, menentukan waktu ujian dan sebagainya. Namun pada kenyataan di lapangan, pelaksanaan manajemen kurikulum sekolah dasar di Kota Bandung masih belum optimal. Dari hasil wawancara dengan beberapa guru sekolah dasar, ditemukan fakta bahwa sebagian guru kesulitan dalam perencanaan dan evaluasi kurikulum sesuai dengan Kurikulum 2013.

Faktor lain yang mempengaruhi kinerja mengajar guru adalah komitmen. Komitmen merupakan salah satu faktor internal yang berasal dalam diri guru. Berdasarkan UU Nomor 14 Tahun 2005 tentang Guru dan Dosen pada Bab III Pasal 7 disebutkan bahwa profesi guru merupakan bidang pekerjaan khusus yang harus memiliki komitmen untuk meningkatkan mutu pendidikan, keimanan, ketakwaan, dan akhlak mulia.

Kalfika (2016) mengemukakan bahwa guru yang telah memiliki komitmen tinggi maka ia akan disiplin waktu, selalu hadir untuk mulai mengajar di kelas dan selesai tepat pada waktunya. Namun, pada kenyataannya sebagian guru sekolah dasar di Kota Bandung masih memiliki disiplin mengajar yang rendah (Anggraeni, 2016).

Berdasarkan penelitian terdahulu yang dilakukan oleh Kambunandiwan menyebutkan manajemen kurikulum, berpengaruh terhadap kinerja mengajar guru. Selanjutnya, hasil penelitian yang dilakukan oleh Kalfika (2016) menunjukkan bahwa komitmen guru berpengaruh positif dan signifikan terhadap kinerja mengajar guru.

Rosita Bestiana (2012) juga melakukan penelitian tentang Hubungan Kepuasan Kerja, Motivasi dan Komitmen Normatif dengan Kinerja Guru SMPN 1 Rantau Selatan - Labuhan Batu. Hasil penelitian ini menunjukkan bahwa seluruh variabel yang dianalisis dengan menggunakan uji $\mathrm{F}$ dan hasilnya diperoleh bahwa kepuasan kerja guru, motivasi kerja dan komitmen normatif dapat dijadikan sebagai faktor dalam menentukan kinerja guru di SMP Negeri 1 Rantau Selatan Kab. Labuhan Batu.

Rosdiana (2013) melakukan penelitian dengan judul Pengaruh Kompetensi Guru Dan Komitmen Mengajar Terhadap Efektivitas Proses Pembelajaran Serta Implikasinya Pada Hasil Belajar Siswa Dalam Mata Pelajaran Ekonomi. Dari hasil penelitian ini diperoleh informasi bahwa terdapat pengaruh kompetensi guru dan komitmen 
mengajar terhadap hasil belajar siswa serta terdapat pengaruh tidak langsung kompetensi guru dan komitmen mengajar terhadap hasil belajar siswa melalui efektivitas proses pembelajaran.
Berdasarkan uraian di atas, maka penelitian ini mengkaji tentang pendidikan sekolah dasar di Kota Bandung khususnya pengaruh manajemen kurikulum dan komitmen guru terhadap kinerja mengajar guru sekolah dasar.

\section{METODE PENELITIAN}

Penelitian ini menggunakan metode deskriptif dengan pendekatan kuantitatif. Metode deskriptif merupakan metode yang ditujukan untuk memecahkan masalah yang terjadi pada masa sekarang yang dilaksanakan dengan melalui prosedur pengumpulan data, mengklasifikasi data, dan kemudian dilakukan penarikan kesimpulan (Sugiyono, 2013).

Dalam penelitian ini, variabel yang akan diteliti adalah manajemen kurikulum dan komitmen guru sebagai variabel independen, sedangkan kinerja mengajar guru sebagai variabel dependen. Indikator manajemen kurikulum terdiri atas pengembangan, pengorganisasian, pelaksanaan, dan pengawasan kurikulum. Sementara itu, indikator komitmen guru terdiri atas komitmen pada peserta didik, komitmen pada sekolah, komitmen pada profesi, dan komitmen pada orang tua/wali siswa. Sedangkan indikator kinerja mengajar guru adalah perencanaan pembelajaran, pelaksanaan pembelajaran dan evaluasi/penilaian dan tindak lanjut pembelajaran.

Populasi penelitian ini adalah seluruh Sekolah Dasar Negeri Kota Bandung yang sebanyak 274 sekolah. Sampel sekolah sebanyak 30 sekolah diambil berdasarkan teknik cluster random sampling. Penggunaan teknik ini mengingat wilayah Kota Bandung yang cukup luas dan terdiri dari 30 Kecamatan. Penarikan sampel akan diambil berdasarkan cluster wilayah administratif, kecamatan, sekolah, dan selanjutnya didapatkan sampel individu (Arikunto dalam Riduan, 2010).

Peneliti membagi wilayah pemerintahan kota Bandung ke dalam depalan Sub Wilayah Kota (SWK). Pembagian wilayah tersebut didasarkan pada Peraturan Daerah Kota Bandung Nomor 10 Tahun 2015 tentang Rencana Detail Tata Ruang dan Peraturan Zonasi Kota Bandung Tahun 2015 2035. Dari delapan SWK tersebut, kemudian diambil satu kecamatan dalam setiap wilayah. Setelah itu, sekolah diambil sebanyak $40 \%$ dari jumlah sekolah dasar pada kecamatan yang terpilih, dan selanjutnya dari masing-masing sekolah yang terpilih akan diambil responden guru sebanyak $20 \%$.

Teknik pengolahan data dalam penelitian ini menggunakan analisis regresi linier berganda untuk mengetahui ada tidaknya hubungan antar gejala (variabel), hubungan tersebut positif atau negatif dan seberapa signifikan hubungan antar variabel tersebut.

\section{HASIL PENELITIAN}

\section{Deskripsi Kinerja Mengajar Guru}

Hasil perhitungan nilai rata-rata variabel kinerja mengajar guru $(\mathrm{Y})$ dengan metode WMS diperoleh nilai rata-rata sebesar 3,54. Nilai rata- rata tersebut masuk ke dalam kategori "sangat tinggi”, artinya bahwa rata-rata responden cenderung menilai bahwa kinerja mengajar guru 
sudah sangat tinggi berdasarkan dimensi dan indikator yang digunakan dalam penelitian ini.

Terdapat tiga dimensi dalam variabel kinerja mengajar guru yaitu perencanaan pembelajaran, pelaksanaan pembelajaran dan evaluasi/penilaian dan tindak lanjut pembelajaran. Berikut adalah skor rata-rata ketiga dimensi.

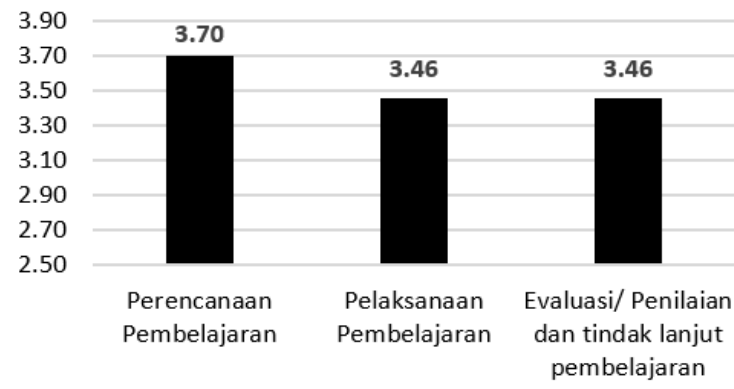

Gambar 1

Penyebaran Skor Rata-rata Dimensi Variabel Kinerja Mengajar Guru

\section{Deskripsi Manajemen Kurikulum}

Hasil perhitungan nilai rata-rata variabel manajemen kurikulum diperoleh nilai rata-rata sebesar 3,49. Nilai rata-rata tersebut masuk ke dalam kategori "sangat baik", artinya bahwa ratarata responden cenderung menilai bahwa manajemen kurikulum sudah sangat baik berdasarkan dimensi dan indikator yang digunakan dalam penelitian ini.

Terdapat empat dimensi dalam variabel manajemen kurikulum yaitu pengembangan, pengorganisasian, pelaksanaan, dan pengawasan kurikulum. Berikut adalah skor rata-rata keempat dimensi.

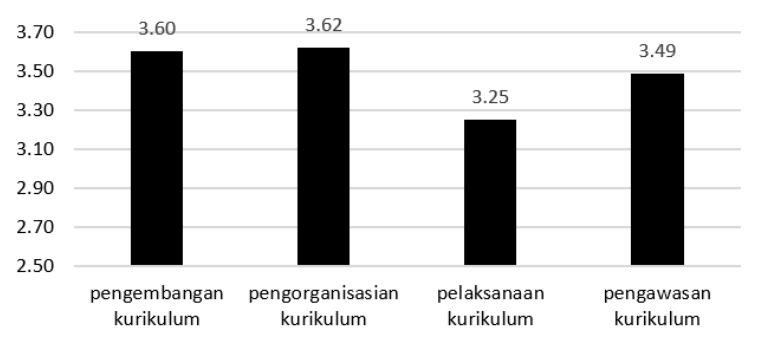

Gambar 2
Penyebaran Skor Rata-rata Dimensi Variabel Manajemen Kurikulum

\section{Deskripsi Komitmen Guru}

Hasil perhitungan nilai rata-rata variabel komitmen guru diperoleh nilai rata-rata sebesar 3,46. Nilai rata-rata tersebut masuk ke dalam kategori "sangat tinggi", artinya bahwa rata-rata responden cenderung menilai bahwa komitmen guru sudah sangat tinggi berdasarkan dimensi dan indikator yang digunakan dalam penelitian ini.

Terdapat empat dimensi dalam variabel komitmen guru, yaitu Rata-rata komitmen pada peserta didik, komitmen pada sekolah, komitmen pada profesi, dan komitmen pada orang tua/wali siswa. Berikut adalah skor rata-rata keempat dimensi.

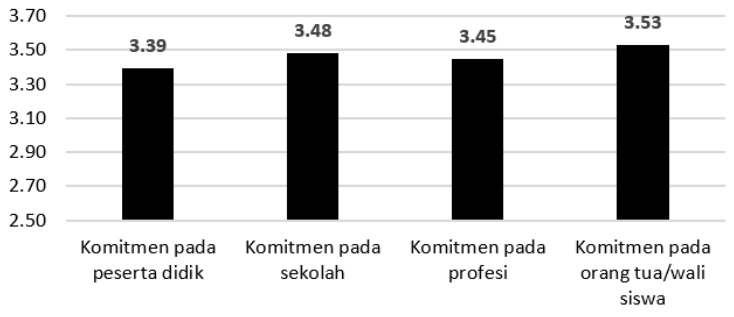

Gambar 3

Penyebaran Skor Rata-rata Dimensi Variabel Komitmen Guru

\section{Pengujian Hipotesis}

\section{Pengaruh Manajemen Kurikulum terhadap} Kinerja Mengajar Guru

Hipotesis dalam penelitian ini adalah terdapat pengaruh antara manajemen kurikulum terhadap kinerja mengajar guru. Berdasarkan hasil perhitungan, maka diperoleh hasil koefisien korelasi antara manajemen kurikulum dengan kinerja mengajar guru adalah 0,539 yang berarti manajemen kurikulum memiliki hubungan yang cukup kuat dengan kinerja mengajar guru. 
Kemudian diperoleh bahwa nilai $\mathrm{R}^{2}$ manajemen kurikulum terhadap kinerja mengajar guru sebesar 0,352 atau $35,2 \%$. Hal ini menunjukkan bahwa besarnya pengaruh manajemen kurikulum terhadap kinerja mengajar guru adalah sebesar 35,2\% sedangkan sisanya yaitu sebesar $64,8 \%$ dipengaruhi oleh variabel lain.

Persamaan model regresi yang terbentuk adalah $\hat{Y}=57,558+0,446 X_{1}$. Interpretasi dari persamaan tersebut bahwa jika variabel manajemen kurikulum $\left(\mathrm{X}_{1}\right)$ dengan kinerja mengajar guru $(\mathrm{Y})$ diukur dengan menggunakan instrumen yang dikembangkan dalam penelitian ini, maka setiap perubahan skor manajemen kurikulum $\left(\mathrm{X}_{1}\right)$ sebesar satu satuan, maka estimasi skor kinerja mengajar guru (Y) akan berubah sebesar 0,446 satuan pada arah yang sama.

\section{Pengaruh Komitmen Guru terhadap Kinerja Mengajar Guru}

Hipotesis dalam penelitian ini adalah terdapat pengaruh antara komitmen guru terhadap kinerja mengajar guru. Berdasarkan hasil perhitungan, diperoleh koefisien korelasi antara komitmen guru dengan kinerja mengajar guru adalah 0,856 yang berarti komitmen guru memiliki hubungan yang sangat kuat dengan kinerja mengajar guru. Kemudian diperoleh bahwa nilai $\mathrm{R}^{2}$ komitmen guru terhadap kinerja mengajar guru sebesar 0,733 atau $73,3 \%$. Hal ini menunjukkan bahwa besarnya pengaruh komitmen guru terhadap kinerja mengajar guru adalah sebesar 73,3\% sedangkan sisanya yaitu sebesar $26,7 \%$ dipengaruhi oleh variabel lain.

Persamaan model regresi yang terbentuk adalah $\hat{Y}=40,100+0,543 X_{2}$. Interpretasi dari persamaan tersebut bahwa jika variabel komitmen guru $\left(\mathrm{X}_{2}\right)$ dengan kinerja mengajar guru $(\mathrm{Y})$ diukur dengan menggunakan instrumen yang dikembangkan dalam penelitian ini, maka setiap perubahan skor komitmen guru $\left(\mathrm{X}_{2}\right)$ sebesar satu satuan, maka estimasi skor kinerja mengajar guru (Y) akan berubah sebesar 0,543 satuan pada arah yang sama.

Pengaruh Manajemen Kurikulum dan Komitmen Guru terhadap Kinerja Mengajar Guru

Hipotesis dalam penelitian ini adalah terdapat pengaruh antara manajemen kurikulum $\left(\mathrm{X}_{1}\right)$ dan komitmen guru $\left(\mathrm{X}_{2}\right)$ secara bersama-sama terhadap kinerja mengajar guru $(\mathrm{Y})$. berdasarkan hasil perhitungan, diperoleh koefisien korelasi antara manajemen kurikulum dan komitmen guru dengan kinerja mengajar guru adalah 0,882 yang berarti manajemen kurikulum dan komitmen guru secara bersama-sama memiliki hubungan yang sangat kuat dengan kinerja mengajar guru. Kemudian diperoleh bahwa nilai $\mathrm{R}^{2}$ manajemen kurikulum dan komitmen guru secara bersamasama terhadap kinerja mengajar guru sebesar 0,777 atau $77,7 \%$. Hal ini menunjukkan bahwa besarnya pengaruh manajemen kurikulum dan komitmen guru secara bersama-sama terhadap kinerja mengajar guru adalah sebesar $77,7 \%$ sedangkan sisanya yaitu sebesar $22,3 \%$ dipengaruhi oleh variabel lain.

Persamaan model regresi yang terbentuk adalah $\hat{Y}=33,454+0,179 X_{1}+0,470 X_{2}$. Interpretasi dari persamaan tersebut bahwa jika variabel manajemen kurikulum (X1) dan komitmen guru (X2) dengan kinerja mengajar guru (Y) diukur secara bersama-sama dengan menggunakan instrumen yang dikembangkan dalam penelitian ini, maka setiap perubahan skor manajemen kurikulum $\left(\mathrm{X}_{1}\right)$ dan komitmen guru $\left(\mathrm{X}_{2}\right)$ sebesar satu satuan, maka estimasi skor kinerja mengajar guru (Y) akan berubah sebesar 
0,179 satuan $\mathrm{X}_{1}$ dan 0,470 satuan $\mathrm{X}_{2}$ pada arah yang sama. Besarnya pengaruh antar masingmasing variabel digambarkan sebagai berikut.

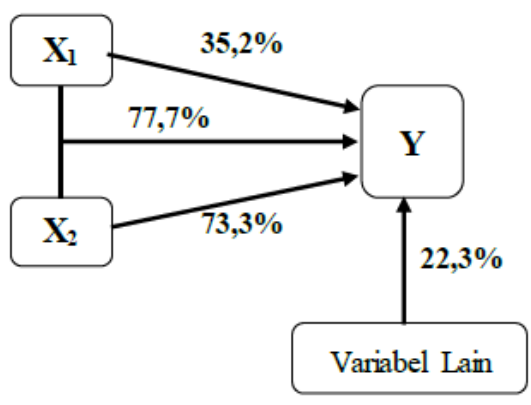

Gambar 4. Pengaruh Manajemen Kurikulum dan Komitmen Guru terhadap Kinerja Mengajar Gur

\section{PEMBAHASAN}

\section{Kinerja Mengajar Guru}

Kinerja mengajar guru dalam penelitian ini didefinisikan sebagai kemampuan guru dalam melaksanakan proses pembelajaran yang meliputi perencanaan, pelaksanaan, evaluasi serta tindak lanjut pembelajaran dalam rangka pembinaan peserta didik untuk mencapai tujuan pembelajaran. Sementara itu, Jones et al. (2006) mengartikan kinerja mengajar guru sebagai cara untuk menjalankan tugas pokoknya, yaitu dalam hal perencanaan proses pembelajaran, pengajaran, dan penilaian yang dilakukan dalam rangka mencapai tujuan yang telah ditetapkan.

Sejalan dengan definisi tersebut, berdasarkan Undang-undang Nomor 14 Tahun 2005 Bab IV Pasal 20 (a) menyatakan bahwa standar prestasi kerja guru dalam melaksanakan tugas keprofesionalannya, guru berkewajiban untuk merencanakan pembelajaran, melaksanakan proses pembelajaran yang bermutu, serta menilai dan mengevaluasi hasil pembelajaran.

Berdasarkan temuan yang diperoleh dari hasil analisis data penelitian pada variabel kinerja mengajar guru Sekolah Dasar Negeri di Kota Bandung berada kategori "sangat tinggi".

Hasil analisis deskriptif menunjukkan bahwa dimensi perencanaan pembelajaran dikategorikan "sangat tinggi" dengan skor rata-rata
3,70. Sebelum melaksanakan pembelajaran, seorang guru harus mengadakan persiapan terlebih dahulu agar proses belajar-mengajar dapat berjalan dengan lancar dan tujuan pembelajaran dapat tercapai (Ibrahim \& Sukmadinata, 2010).

Hasil analisis deskriptif menunjukkan bahwa dimensi pelaksanaan pembelajaran dikategorikan "sangat tinggi" dengan skor rata-rata 3,46 . Angka tersebut masih berada di bawah dimensi perencanaan pembelajaran. Pelaksanaan pembelajaran di sekolah dasar sesuai dengan K13 adalah merupakan pembelajaran tematik. Haji (2015) menyebutkan bahwa pelaksanaan pembelajaran tematik yang ideal bagi sekolah dasar dalah dilakukan dengan menggunakan tiga tahapan kegiatan yaitu kegiatan pembukaan, kegiatan inti, dan kegiatan penutup.

Berdasarkan kecenderungan jawaban yang dipilih oleh responden, yang masih kurang dalam pelaksanaan pembelajaran sekolah dasar negeri di Kota Bandung adalah dalam pelaksanaan kegiatan inti terutama dalam dalam memanfaatkan peraga dan sarana pembelajaran dalam kegiatan pembelajaran. Selain itu menurut Sungkono (2006), kekurangan yang sering terjadi dalam pelaksanaan pembelajaran tematik, yakni tidak setiap guru mampu mengintegrasikan kurikulum 
dengan konsep-konsep yang ada dalam setiap tema secara tepat.

Dalam rangka meningkatkan pelaksanaan pembelajaran di sekolah dasar, pelaksanaan pembelajaran harus didukung oleh keterampilan dan kompetensi guru, serta kemampuan guru dalam mengintegrasi kurikulum dengan konsepkonsep yang ada dalam setiap tema pelajaran (Sungkono, 2006). Dukungan sarana dan prasarana yang memadai yang berisi berbagai sumber belajar yang dibutuhkan juga akan dapat meningkatkan pelaksanaan pembelajaran tematik oleh guru.

Hasil analisis deskriptif menunjukkan bahwa dimensi evaluasi atau penilaian dan tindak lanjut pembelajaran dikategorikan "sangat tinggi" dengan skor rata-rata 3,46. Evaluasi/penilaian pembelajaran tematik difokuskan pada evaluasi proses dan hasil (Sungkono, 2006). Evaluasi proses diarahkan pada tingkat keterlibatan, minat dan semangat siswa dalam proses pembelajaran, sedangkan evaluasi hasil lebih diarahkan pada tingkat pemahaman dan penyikapan siswa terhadap substansi materi dan manfaatnya bagi kehidupan siswa sehari-hari.

Dalam meningkatkan evaluasi/penilaian pembelajaran, guru dapat menggunakan instrumen untuk mengungkap pemahaman siswa terhadap materi pelajaran, guru dapat memberikan suatu tes perbuatan atau keterampilan untuk mengetahui tingkat kemampuan siswa dalam melakukan suatu tugas, serta guru dapat melakukan wawancara atau dialog secara informal untuk mengungkap sikap siswa terhadap materi pelajaran.

\section{Manajemen Kurikulum}

Manajemen kurikulum dalam penelitian ini didefinisikan sebagai sebuah sistem pengelolaan kurikulum sekolah untuk menciptakan pengalaman belajar yang bermutu bagi peserta didik. Sejalan dengan hal tersebut, Hamalik (2012) menyebutkan bahwa pelaksanaan manajemen kurikulum di tingkat sekolah merupakan tanggung jawab kepala sekolah untuk melaksanakan kurikulum di lingkungan sekolah yang dipimpinnya. Hal tersebut dikarenakan kepala sekolah sebagai pemimpin dan termasuk memimpin pelaksanaan kurikulum. Kepala sekolah merupakan administrator dalam pelaksanaan kurikulum yang berperan dalam perencanaan program, pengorganisasian staf, dan penilaian terhadap personal sekolah.

Berdasarkan temuan yang diperoleh dari hasil analisis data penelitian pada variabel manajemen kurikulum Sekolah Dasar Negeri di Kota Bandung berada kategori "sangat baik". Hal tersebut menunjukkan bahwa secara umum pelaksanaan manajemen kurikulum Sekolah Dasar Negeri di Kota Bandung sudah baik.

Hasil analisis deskriptif menunjukkan bahwa dimensi pengembangan kurikulum dikategorikan "sangat baik" dengan skor rata-rata 3,60. Pada tahap institusi, kegiatan pengembangan kurikulum dilakukan di setiap lembaga pendidikan (Hernawan, 2007). Dalam pengembangan kurikulum, kepala sekolah harus mampu dalam memfasilitasi sekolah untuk membentuk dan memberdayakan tim pengembang kurikulum untuk mengembangkan kurikulum sesuai dengan kebutuhan dan kemampuan masing-masing sekolah (Rusman, 2009).

Hasil analisis deskriptif menunjukkan bahwa dimensi pengorganisasian kurikulum dikategorikan "sangat baik" dengan skor rata-rata 3,62. Hal ini menunjukkan bahwa kepala sekolah melakukan penyusunan jadwal pelajaran, melakukan pembagian beban mengajar serta beban belajar. Penyusunan jadwal pelajaran didasarkan pada kewajiban jam mengajar guru dan berdasarkan hasil musyawarah bersama antar 
kepala sekolah dan guru. Pengaturan tugas dan kewajiban guru disesuaikan dengan bidang keahlian dan minat guru dan didasarkan pada beban tugas minimal dan keahliannya. Dengan demikian setiap guru diharapkan memiliki motivasi untuk berprestasi serta berusaha untuk merealisasikan program sekolah secara sinergi antara kepala sekolah, guru, tenaga kependidikan, serta orang tua (Sudarsyah \& Nurdin, 2010). Sementara itu, pembagian beban belajar disesuaikan dengan kebutuhan dan karakteristik peserta didik dalam rangka menciptakan pengalaman belajar yang bermutu bagi peserta didik.

Hasil analisis deskriptif menunjukkan bahwa dimensi pelaksanaan kurikulum dikategorikan "sangat baik" dengan skor rata-rata 3,25. Hal ini dilihat dari pelaksanaan kegiatan pembelajaran serta pelaksanaan supervisi oleh kepala sekolah. Walaupaun dimensi pelaksanaan kurikulum sudah baik, namun dimensi ini masih kurang dari ketiga dimensi lainnya. Kurangnya pelaksanaan kurikulum sebagian besar disebabkan oleh guru yang kesulitan dalam menerjemahkan kurikulum 2013 yang memiliki pendekatan tematik intergatif. Guru kesulitan dalam mengubah pola pikir baru sesuai dengan pembelajaran tersebut. Dalam hal ini peran kepala sangat penting dalam memberikan bimbingan, arahan dan dukungan kepada para guru untuk mengembangkan dan memahami kurikulum dengan pendekatan tematk pada jenjang sekolah dasar.

Pelaksanaan kurikulum dengan pembelajaran tematik pada prinsipnya sama dengan pembelajaran pada umumnya. Namun yang berbeda adalah pada pembelajaran tematik tidak mengenal mata pelajaran, melainkan tema-tema tertentu yang mencakup berbagai mata pelajaran. Dalam hal ini, guru dan kepala sekolah dituntut untuk mampu melaksanakan kurikulum yang sudah disusun berdasarkan perencanaan kurikulum yang sudah dibuat.

Pengawasan kurikulum dikategorikan "sangat baik" dengan skor rata-rata 3,49. Hal ini dilihat dari pengawasan kurikulum oleh kepala sekolah dan tindak lanjut hasil pengawasan kurikulum. Suhardan (2014) mengemukakan bahwa pengawasan di sekolah menekankan pada pekerjaan yang harus dijalankan dengan benar oleh semua unur pelaksananya termasuk guru, walaupun harus memaksan orang yang mengerjakannya.

Tindak lanjut dari adanya pengawasan kurikulum menurut Rusman (2009) adalah untuk mengupayakan kesesuaian kurikulum dengan kebutuhan siswa dan kemajuan ilmu pengetahuan, teknologi, dan seni (IPTEKS); tuntutan dan kebutuhan masyarakat, serta kebutuhan stakeholders; mengidentifikasi kebutuhan bagi pengembangan kurikulum lokal; mengevaluasi pelaksanaan kurikulum di sekolah; serta melakukan penelitian dan pengembangan terhadap usaha untuk meningkatkan kualitas dan manajemen sekolah bermutu.

Sementara itu, Glickman et al. (2014) menyebutkan bahwa kepala sekolah sebagai pengawas yang ingin memfasilitasi perubahan dalam tujuan kurikulum, konten, organisasi, dan format kurikulum harus ingat bahwa keberhasilan kurikulum didasarkan pada guru yang mampu mengubah pola pikir dan melibatkan diri mereka dalam pengembangan kurikulum di sekolah.

\section{Komitmen Guru}

Komitmen guru dalam penelitian ini didefinisikan sebagai sikap dan tanggung jawab serta kesetiaan guru dalam melaksanakan tugas dan kewajibannya sesuai dengan aturan untuk mencapai tujuan pendidikan. Seorang guru yang 
berkomitmen tinggi akan bertanggung jawab terhadap sekolah dan profesinya dengan sukarela dan menciptakan iklim sekolah yang kondusif serta berusaha mewujudkan keberhasilan pendidikan dan pengajaran.

Berdasarkan temuan yang diperoleh dari hasil analisis data penelitian pada variabel komitmen guru Sekolah Dasar Negeri di Kota Bandung berada pada kategori "sangat tinggi". Hal tersebut menunjukkan bahwa secara umum komitmen guru Sekolah Dasar Negeri di Kota Bandung sudah tinggi.

Hasil analisis deskriptif menunjukkan bahwa dimensi komitmen pada peserta didik dikategorikan "sangat tinggi" dengan skor rata-rata 3,39. Hal ini dilihat dari bagaimana perlakuan guru terhadap peserta didik serta tanggung jawab guru terhadap pembelajaran peserta didik. Prayitno (2015) menjelaskan bahwa guru yang berkomitmen akan selalu berupaya mendidik dan membimbing peserta didik dalam memunculkan potensi maksimalnya untuk bermanfaat bagi diri, lingkungan dan negara.

Matthew (2015) juga menyebutkan bahwa guru yang berkomitmen pada peserta didik akan berusaha untuk memenuhi kebutuhan masingmasing peserta didik. Kelompok kelas merupakan sebuah kelompok besar yang terdiri dari banyak individu unik dan berbeda serta dengan kebutuhan unik pula. Seorang guru yang berkomitmen berusaha untuk memenuhi kebutuhan peserta didik dengan menyediakan berbagai metode pengajaran, termasuk instruksi langsung, mengelompokkan peserta didik, dan menata ulang kelompok sesuai kebutuhan. Untuk menjangkau setiap peserta didik, guru harus berusaha memotivasi setiap individu, melibatkannya dalam pembelajaran, dan memberikan pengajaran sesuai dengan karakteristik dan kebutuhan peserta didik. Selain itu, guru juga harus menjadi pendamping siswa dan berusaha menggali potensi yang dimiliki peserta didik untuk dikembangkan.

Hasil analisis deskriptif menunjukkan bahwa dimensi komitmen pada sekolah dikategorikan "sangat tinggi" dengan skor rata-rata 3,48. Komitmen pada sekolah diukur berdasarkan tingkat keyakinan dan penerimaan guru terhadap tujuan dan nilai sekolah, usaha untuk mewujudkan tujuan dan nilai sekolah, serta keinginan guru untuk menjaga keanggotaannya di sekolah. Komitmen guru pada sekolah dapat pula dianggap sebagai komitmen organisasi. Luthans (1995) menyebutkan bahwa seorang yang memiliki komitmen organisasi memiliki keinginan untuk tetap menjadi bagian dari suatu organisasi, bersedia untuk mencapai peningkatan usaha atas nama organisasi, serta memiliki keyakinan dan penerimaan nilai dan tujuan organisasi.

Hasil analisis deskriptif menunjukkan bahwa dimensi komitmen pada profesi dikategorikan "sangat tinggi" dengan skor rata-rata 3,45. Hal ini dilihat dari kekuatan motivasi dan keterikatan guru dengan pekerjaan, serta bagaimana upaya guru dalam meningkatkan pengetahuan dan kemampuan sebagai bentuk pengembangan profesi.

Guru merupakan jabatan atau profesi yang memerlukan keahlian khusus sebagai guru. Pekerjaan ini tidak bisa dilakukan oleh orang lain yang tidak memiliki keahlian untuk melakukan kegiatan atau pekerjaan sebagai guru (Usman, 2016). Oleh karena itu, seorang guru harus memiliki komitmen terhadap profesi dan pekerjaannya terutama dalam mengembangkan kompetensi, pengetahuan, dan kemampuannya, serta guru harus peka dan tanggap terhadap perubahan dan pembaruan ilmu pengetahuan dan 
teknologi sejalan dengan kebutuhan masyarakat dan perkembangan zaman.

Komitmen pada ornag tua/wali siswa. Berdasarkan hasil analisis deskriptif menunjukkan bahwa dimensi komitmen pada ornag tua/wali siswa dikategorikan "sangat tinggi" dengan skor rata-rata 3,53. Hal ini dilihat dari komunikasi guru dengan orang tua serta pelaporan hasil belajar peserta didik kepada orang tua. Guru yang berkomitmen pada orang tua akan berusaha untuk berkomunikasi secara berkala dengan orang tua/ wali siswa mengenai kondisi dan kemajuan peserta didik dan memberikan informasi yang objektif mengenai kondisi dan kemajuan peserta didik. guru yang berkomitmen juga akan memberikan kesempatan kepada orang tua untuk berkonsultasi terkait dengan minat dan bakat peserta didik serta memberikan laporan hasil evaluasi belajar peserta didik kepada orang tua secara obyektif.

Pengaruh Manajemen Kurikulum terhadap Kinerja Mengajar Guru

Berdasarkan hasil analisis yang telah dilakukan sebelumnya diperoleh hasil bahwa manajemen kurikulum berpengaruh terhadap kinerja mengajar guru Sekolah Dasar Negeri di Kota Bandung dengan nilai sebesar 35,2\%, sementara sisanya sebesar $64,8 \%$ dipengaruhi oleh variabel lain.

Hasil penelitian ini didukung oleh penelitian yang dilakukan oleh Kambunandiwan (2013) yang menyatakan bahwa manajemen pembelajaran, manajemen Kurikulum, manajemen prasarana, dan manajemen humas berpengaruh secara signifikan terhadap kinerja guru. Selanjutnya, menurut Rusman (2009) salah satu fungsi dari manajemen kurikulum adalah untuk meningkatkan efektivitas kinerja guru maupun aktivitas siswa dalam mencapai tujuan pembelajaran. Pengelolaan kurikulum yang profesional, efektif, dan terpadu dapat memberikan motivasi pada kinerja guru maupun aktivitas siswa dalam belajar.

Sebagai salah satu variabel signifikan yang mempengaruhi kinerja mengajar guru, maka dalam rangka meningkatkan kinerja mengajar guru Sekolah Dasar Negeri di Kota Bandung perlu dilakukan upaya untuk meningkatkan manajemen kurikulum. Gambaran tentang pelaksanaan manajemen kurikulum Sekolah Dasar Negeri di Kota Bandung pada umumnya sudah berlangsung baik, namun masih terdapat beberapa hambatan dan kendala terutama dalam pelaksanaan kurikulum. Kurangnya ketersediaan sarana prasarana penunjang dan buku yang sesuai dengan Kurikulum 2013 membuat para guru kesulitas dalam mengimplementasikan kurikulum. Selain itu, guru kesulitan dalam menterjemahkan kurikulum baru yaitu kurikulum 2013 ke dalam program pengajaran semester serta sulit untuk mengubah pola pikir lama ke pola pikir baru sesuai dengan perkembangan yang terjadi dalam kurikulum.

Oleh karena itu diperlukan adanya peningkatan sarana dan prasarana serta buku yang sesuai dengan Kurikulum 2013. Selain itu, kepala sekolah diharapkan dapat meningkatkan kualitas dorongan, bimbingan, dan dukungan kepada guru dengan melakukan supervisi secara terjadwal kepada para guru dan menyampaikan hasilnya sebagai bahan masukan, bimbingan serta pembinaan kepala sekolah kepada guru. Pelaksanaan supervisi tersebut diharapkan dapat menunjang kinerja mengajar guru serta dapat mengembangkan proses belajar mengajar melalui peningkatan manajemen kurikulum. 


\section{Pengaruh Komitmen Guru terhadap Kinerja Mengajar Guru}

Komitmen guru adalah faktor kunci yang mempengaruhi proses belajar mengajar. Hal ini mengandung pemahaman bahwa guru sebagai individu memiliki keterlibatan dengan sekolah, dengan materi pelajaran, tujuan pembelajaran, dan niat guru untuk mempertahankan keanggotaan organisasi, semua ini akan berpengaruh terhadap proses pembelajaran yang dilakukannya (Graham, 1996).

Berdasarkan hasil analisis yang telah dilakukan sebelumnya diperoleh hasil bahwa komitmen guru berpengaruh terhadap kinerja mengajar guru Sekolah Dasar Negeri di Kota Bandung dengan nilai sebesar $73,3 \%$, sementara sisanya sebesar $26,7 \%$ dipengaruhi oleh variabel lain.

Hasil penelitian ini didukung oleh penelitian yang dilakukan oleh Sukmawati \& Herawan (2016) yang menyatakan bahwa terdapat pengaruh yang positif dan signifikan antara komitmen guru terhadap mutu kinerja mengajar guru. Komitmen guru berpengaruh terhadap mutu kinerja mengajar guru hal ini disebabkan karena ketika guru memiliki komitmen tinggi yaitu semangat, keinginan, keyakinan, dedikasi, dan loyalitas yang kuat untuk memberikan usaha dan energinya terhadap tugasnya mengajar maka mutu kinerjanya dalam mengajar pun akan meningkat.

Selaras dengan penelitian sebelumnya, Sukamto \& Pardjono (2016) juga menyatakan bahwa komitmen guru memiliki pengaruh positif dan sifnifikan terhadap kinerja guru dimana peningkatan kinerja guru dapat dilakukan dengan meningkatkan komitmen terhadap proses belajar mengajar, kurikulum dan kebijakan sekolah.

Komitmen guru merupakan salah satu komponen pokok yang mendukung kinerja guru.
Beer (2009) mengemukakan bahwa komitmen yang tinggi berbanding lurus dengan kinerja tinggi. Keselarasan kinerja guru akan terjadi ketika total sistem organisasi sekolah (struktur, sistem, manusia, dan budaya) sesuai dengan sasaran dan strategi kinerja yang ingin dicapai sesuai dengan tujuan pendidikan.

Sejalan dengan pendapat tersebut, Komariah (2014) mengemukakan bahwa performance $=$ (ability $x$ motivation + commitment). Hal tersebut bermakna bahwa kinerja ditentukan oleh kemampuan yang diperoleh dari hasil pendidikan, pelatihan dan pengalaman; motivasi yang merupakan perhatian khusus dari hasrat seorang pegawai dalam melakukan suatu pekerjaan dengan baik; dan kesetiaan terhadap janji atau kontrak kerja sebagai pegawai.

\section{Pengaruh Manajemen Kurikulum dan Komitmen Guru terhadap Kinerja Mengajar Guru}

Berdasarkan hasil analisis yang telah dilakukan sebelumnya diperoleh hasil bahwa manajemen kurikulum dan komitmen guru secara bersama-sama berpengaruh terhadap kinerja mengajar guru Sekolah Dasar Negeri di Kota Bandung dengan nilai sebesar $77,7 \%$, sementara sisanya sebesar $22,3 \%$ dipengaruhi oleh variabel lain. Apabila dilihat dari besarnya koefisien korelasi, koefisien korelasi manajemen kurikulum (X1) dan komitmen guru (X2) secara bersamasama dengan kinerja mengajar guru $(\mathrm{Y})$ adalah sebesar 0,882 , sehingga dapat disimpulkan bahwa manajemen kurikulum dan komitmen guru secara bersama-sama memiliki hubungan dengan kinerja mengajar guru ke arah positif yang sangat kuat. Hal ini menunjukkan bahwa bahwa jika pelaksanaan manajemen kurikulum sudah dilakukan dengan baik disertai dengan komitmen guru yang tinggi, 
maka kinerja mengajar guru Sekolah Dasar Negeri di Kota Bandung akan lebih optimal.

Setelah dilakukan analisis secara individu maupun secara bersama-sama, berdasarkan hasil analisis diketahui bahwa pengaruh kedua variabel secara bersama-sama lebih tinggi daripada pengaruh kedua variabel secara individu. Hal ini menunjukkan bahwa semakin banyak variabel yang dinyatakan berpengaruh signifikan maka kinerja mengajar guru akan semakin meningkat. Dengan demikian, untuk menghasilkan kinerja mengajar guru yang optimal, tidak bisa dilakukan hanya dengan melihat salah satu variabel saja, namun dengan melihat kedua variabel yang mempengaruhi secara bersama-sama. Selain itu, tidak menutup kemungkinan bahwa masih banyak variabel yang mempengaruhi kinerja mengajar guru namun belum diteliti pada penelitian ini.

\section{SIMPULAN DAN REKOMENDASI}

Kinerja mengajar guru, pelaksanaan manajemen kurikulum, serta komitmen guru Sekolah Dasar Negeri di Kota Bandung berada pada kategori "sangat tinggi". Hal tersebut menunjukkan bahwa secara umum ketiga variable tersebut sudah sangat tinggi atau sudah baik.

Pada variabel kinerja mengajar guru, aspek pelaksanaan pembelajaran serta evaluasi/penilaian dan tindak lanjut pembelajaran masih berada di bawah perencanaan pembelajaran. Padahal seharusnya pelaksanaan pembelajaran memiliki nilai yang lebih tinggi karena merupakan hal yang utama dalam proses belajar-mengajar secara keseluruhan.

Sama halnya dengan variabel kinerja mengajar guru, pada manajemen kurikulum, pelaksanaan kurikulum masih berada di bawah ketiga dimensi lainnya. Hal tersebut dikarenakan beberapa hambatan antara lain kurangnya ketersediaan sarana prasarana penunjang. Selain itu, guru kesulitan dalam menterjemahkan kurikulum baru yaitu kurikulum 2013 ke dalam program pengajaran semester serta sulit untuk mengubah pola pikir lama ke pola pikir baru sesuai dengan perkembangan yang terjadi dalam kurikulum.

Pada variabel komitmen guru masih terdapat beberapa hal yang menyebabkan kurang tingginya komitmen guru terutama pada dimensi komitmen pada peserta didik yaitu guru masih kesulitan dalam memahami perkembangan psikomotorik siswa. Aspek lain yang cukup rendah adalah komitmen guru terhadap sekolah, yang disebabkan oleh kurangnya usaha guru untuk mewujudkan tujuan dan nilai sekolah. Hal tersebut terlihat dari kurangnya inisiatif guru untuk mengembangkan pembelajaran demi kemajuan sekolah.

Secara parsial, manajemen kurikulum dan komitmen guru memberikan pengaruh yang positif dan signifikan terhadap kinerja mengajar guru dengan pengaruh sebesar 35,2\% unruk manajemen kurikulum dan 73,3\% untuk komitmen guru. Begitupun jika dilihat secara bersama-sama, kedua variabel tersebut memberikan pengaruh yang positif dan signifikan terhadap kinerja mengajar guru dengan pengaruh sebesar 77,7\%. Besarnya pengaruh kedua variabel secara bersama-sama lebih besar dari pengaruh masing-masing variabel secara individu. Dengan demikian, dapat diambil kesimpulan bahwa jika pelaksanaan manajemen kurikulum sudah dilakukan dengan baik disertai dengan komitmen guru yang tinggi, maka kinerja mengajar guru Sekolah Dasar Negeri di Kota Bandung akan lebih optimal. 


\section{DAFTAR PUSTAKA}

Anggraeni, I. (2016). Pengaruh Kinerja

Manajerial Kepala Sekolah dan Kinerja

Mengajar Guru Terhadap Mutu Sekolah

Dasar Negeri di Kota Bandung.

Universitas Pendidikan Indonesia.

Armstrong, M. (2009). Armstrong's Handbook of Performance Management: An EvidenceBased Guide to Delivering High Performance (4th ed., Vol. 128). London: Kogan Page.

Beer, M. (2009). High Commitment High Performance. San Fransisco: Jossey-Bass.

Bestiana, Rosita. (2012). Hubungan Kepuasan Kerja, Motivasi dan Komitmen Normatif dengan Kinerja Guru SMPN 1 Rantau Selatan - Labuhan Batu, Jurnal Tabularasa PPS UNIMED, Vol.9 No.2, Desember 2012, hlm 187-200.

Glickman, C. D., Gordon, S. P., \& Ross-Gordon, J. M. (2014). Supervision and Instructional Leadership: a Developmental Approach (Ninth Edit). New York: Pearson.

Graham, K. C. (1996). Running Ahead Enhancing Teacher Commitment. Journal of Physical Education, Recreation and Dance, 67(1), 45-47.

Haji, S. (2015). Pembelajaran Tematik yang Ideal di SD/MI, 3(1), 56-69.

Hamalik, O. (2012). Manajemen Pengembangan Kurikulum. Bandung: PT Remaja Rosdakarya.

Hernawan, A. H. (2007). Manajemen Kurikulum Pendidikan Dasar di Indonesia. In International Seminar on Education Management (pp. 1-10). Kuala Lumpur: University Malaya Kuala Lumpur.

Ibrahim, R., \& Sukmadinata, N. S. (2010). Perencanaan Pengajaran. Jakarta: PT Rineka Cipta.

Jones, J., Jenkin, M., \& Lord, S. (2006). Developing Effective Teacher Performance. London: Paul Chapman Publishing.

Kalfika, R. (2016). Pengaruh Kepemimpinan Instruksional Kepala Sekolah dan Komitmen Guru Terhadap Kinerja Mengajar Guru Sekolah Dasar di Kota Solok. Universitas Pendidikan Indonesia.
Kambunandiwan, T. (2013). Analisis Manajemen Pembelajaran, Manajemen Kurikulum, Manajemen Prasarana, dan Manajemen Humas Terhadap Kinerja Guru (Studi Pada SMK YPPK Santa Monika Bintuni). STIE Indonesia Malang.

Komariah, A. (2014). Pengaruh Kepemimpinan Transformasional, Iklim Sekolah, Kinerja Mengajar Guru Terhadap Produktivitas Sekolah. Mimbar, 30, No. 1, 118-125.

Komariah, A., \& Triatna, C. (2005). Visionary Leadership Menuju Sekolah Efektif. Bandung: PT Bumi Aksara.

Luthans, F. (1995). Organizational Behaviour (Seventh Ed). Singapore: McGraw-Hill.

Matthew, L. (2015). 5 Professional Commitments You Need to Make as a Teacher. Retrieved December 27, 2017, from http://www.theedadvocate.org/5professional-commitments-you-need-tomake-as-a-teacher/

Mulyana, E. H. (2010). Guru Berkualitas: Profesional dan Cerdas Emosi. Jurnal Saung Guru, 1(2), 1-11.

Peraturan Daerah Kota Bandung Nomor 10 Tahun 2015 tentang Rencana Detail Tata Ruang dan Peraturan Zonasi Kota Bandung Tahun $2015-2035$

Prayitno, E. (2015). Konsistensi dan Komitmen Guru dalam Mencetak Generasi Emas. Jurnal Saung Guru, VII(3), 235-242.

Riduwan. (2010). Skala Pengukuran Variabelvariabel Penelitian. Bandung: Alfabeta.

Rosdiana, Dian. 2013. Pengaruh Kompetensi Guru Dan Komitmen Mengajar Terhadap Efektivitas Proses Pembelajaran Serta Implikasinya Pada Hasil Belajar Siswa Dalam Mata Pelajaran Ekonomi, Jurnal Penelitian Pendidikan, 13(2), 201-208.

Rusman. (2009). Manajemen Kurikulum. Jakarta: PT RajaGrafindo Persada.

Satori, D. (2016). Pengawasan dan Penjaminan Mutu Pendidikan. Bandung: Alfabeta.

Sudarsyah, A., \& Nurdin, D. (2010). Manajemen Implementasi Kurikulum. In Pengelolaan Pendidikan. Bandung: Jurusan Administrasi Pendidikan UPI. 
Sugiyono. (2013). Metode Penelitian Kuantitatif Kualitatif dan R\&D. Bandung: CV. Alfabeta

Suhardan, D. (2014). Supervisi Profesional. Bandung: Alfabeta.

Sukamto, Y., \& Pardjono. (2016). Pengaruh Kompetensi Guru, Komitmen Kerja dan Motivasi Kerja Terhadap Kinerja Guru SMP Andalan di Sleman. Jurnal Penelitian Ilmu Pendidikan, 9(2), 165178.

Sukmawati dan Herawan. 2016. Kepemimpinan Instruksional Kepala Sekolah, Komitmen Guru Dan Mutu Kinerja Mengajar Guru, Jurnal Administrasi Pendidikan, 23(2), 6888.
Sungkono. (2006). Pembelajaran Tematik dan Implementasinya di Sekolah Dasar. Majalah Llmiah Pembelajaran, 2(1), 5158.

Suryosubroto. (2010). Manajemen Pendidikan di Sekolah. Jakarta: Rineka Cipta.

Undang-undang Republik Indonesia Nomor 14 Tahun 2005 tentang Guru dan Dosen

Undang-undang Republik Indonesia Nomor 20 Tahun 2003 tentang Sistem Pendidikan Nasional

Usman, M. U. (2016). Menjadi Guru Profesional. Bandung: PT Remaja Rosdakarya. 